\title{
Phosphorus, beverages, and chronic kidney disease
}

\author{
This article was published in the following Dove Press journal: \\ Nutrition and Dietary Supplements \\ 17 October 2012 \\ Number of times this article has been viewed
}

\section{Biagio Di lorio \\ Lucia Di Micco \\ Serena Torraca \\ Maria Luisa Sirico \\ Nephrology-Medicine Department \\ "A Landolfi" Hospital, Solofra, Italy}

Correspondence: Biagio Di lorio Nefrologia, Ospedale "A Landolgi", via Melito snc, I-83029 Solofra (AV), Italy Email br.diiorio@gmail.com
Abstract: Phosphate is present in food in two forms, ie, organic and inorganic phosphate salts, which are naturally present in food and as phosphates added for industrial and commercial reasons. There is also a high content of added phosphate in beverages, and phosphates in this form are highly absorbable. The real content of phosphate contained in beverages is often unrecognized, and nephrologists do not always take into account the amount of phosphorus that patients ingest in this form.

Keywords: phosphorus, beverages, additive, diet

\section{Introduction}

Management of disorders of bone mineral metabolism in patients with chronic kidney disease is important, in particular because of the tight relationship between serum phosphorus levels and cardiovascular morbidity and mortality. ${ }^{1,2}$ The pathogenesis of bone mineral metabolism disorders is multifactorial, and is characterized by altered serum levels of phosphorus, calcium, and parathyroid hormone, as well as the phosphaturic hormone, FGF-23, a member of the fibroblast growth factor family; however, it is known that retention of phosphate due to dietary ingestion in excess of that appropriate for the level of renal function has a central role. ${ }^{3-7}$ Therefore, control of dietary phosphate ingestion and reduction of intestinal absorption of phosphate in the early stages of chronic kidney disease are needed.

About $60 \%$ of phosphorus contained in food is absorbed in the intestine as free inorganic phosphate, and in adults, the balance between phosphate excretion and intestinal absorption of phosphate is maintained via the kidney. Phosphorus levels remain within the normal range until renal function has decreased dramatically, ${ }^{8}$ but they can still increase, even within the normal range, in the early stages of chronic kidney disease (ie, glomerular filtration rate $50 \mathrm{~mL}$ per minute), and be accompanied by an increase in parathyroid hormone levels. Even earlier, there may be a rise in FGF-23; this hormone has a phosphaturic action and contributes to the balance of phosphate that would be otherwise positive from the earliest stages of chronic kidney disease, especially with an unrestricted diet. ${ }^{9,10}$

Dietary phosphate comes from two sources, ie, either naturally contained in food as an organic phosphate or as inorganic salt bound to biological substances, or it can be an additive for industrial and commercial reasons. As an additive, phosphate is present as an inorganic and highly dissociable salt which is easily absorbable in the intestine; in fact, more than $90 \%$ of phosphate additives are absorbed in the 
intestinal tract, whereas only about $60 \%$ of the phosphate naturally present in food is absorbed, especially if ingested in animal product form as opposed to vegetable product form. ${ }^{11}$ The content of phosphate in beverages is often unrecognized. More than $90 \%$ of this type of phosphate is absorbed, but nephrologists do not always take into account the exact amount of phosphorus that patients ingest through beverages.

\section{Phosphorus content of common beverages}

Savica et $\mathrm{al}^{12}$ reported the phosphate content in common beverages to be as follows: red wine $303 \mathrm{mg} / \mathrm{L}$; white wine $217 \mathrm{mg} / \mathrm{L}$; cola beverages $171 \mathrm{mg} / \mathrm{L}$; light cola $120 \mathrm{mg} / \mathrm{L}$; beer $110 \mathrm{mg} / \mathrm{L}$; coffee $51 \mathrm{mg} / \mathrm{L}$; tea $30 \mathrm{mg} / \mathrm{L}$; orange juice $16 \mathrm{mg} / \mathrm{L}$; lemon juice $10 \mathrm{mg} / \mathrm{L}$; and mineral water 6-10 mg/L.

Kalantar-Zadeh et $\mathrm{al}^{13}$ reports the following concentrations in $\mathrm{mg}$ (based on $12 \mathrm{oz}$ servings): Coca-cola ${ }^{\circledR}$ classic 62 (172 mg/L); Diet cola 27 (75 mg/L); Fanta ${ }^{\circledR} 11$ (30 mg/L); Gatorade $^{\circledR} 36(100 \mathrm{mg} / \mathrm{L}) ;$ Lipton $^{\circledR}$ Brisk tea 97-189 (269-525 mg/L); and Diet Pepsi ${ }^{\circledR} 41$ to 68 (114-189 mg/L). Cupisti and D'Alessandro ${ }^{11}$ report that the concentration of phosphorus in beer is $280 \mathrm{mg} / \mathrm{L}$, and Noori et $\mathrm{al}^{14}$ report that the concentration of phosphorus (based on a $12 \mathrm{oz}$ serving) in cola is $40(111 \mathrm{mg} / \mathrm{L})$. Finally, the National Institute of Research for Food and Nutrition in Italy (http://www.inran. it/646/tabelle_di_composizione_degli_alimenti.html) reports the following concentrations of phosphorus in common beverages: white wine $740 \mathrm{mg} / \mathrm{L}$; beer $280 \mathrm{mg} / \mathrm{L}$; cola $180 \mathrm{mg} / \mathrm{L}$; and orange juice $110 \mathrm{mg} / \mathrm{L}$.

\section{Our data}

In a recent paper, we showed that a very low protein diet $(0.3 \mathrm{~g} / \mathrm{kg}$ bodyweight per day) significantly reduced serum and urinary phosphate levels in patients with chronic kidney disease, ${ }^{15}$ in particular, if the very low protein diet was obtained using low-protein products (pasta and bread), vegetables, essential amino acids, and keto analogs of nonessential amino acids. This diet allowed a reduction in serum phosphate from $4.0 \pm 0.5 \mathrm{mg} / \mathrm{dL}$ to $3.5 \pm 0.6 \mathrm{mg} / \mathrm{dL}$ $(P<0.001)$ and in urinary phosphate from $703 \pm 276 \mathrm{mg} /$ day to $464 \pm 209 \mathrm{mg} /$ day $(P<0.008)$, compared with a usual low protein diet, ${ }^{15}$ which is consistent with a recent report by Moe et al. ${ }^{16}$ However, if we compare the observed urinary phosphate with the expected measurement (from the dietary phosphate intake prescribed) for each patient, the urinary phosphate should be $629 \pm 41 \mathrm{mg}$ /day in a low protein

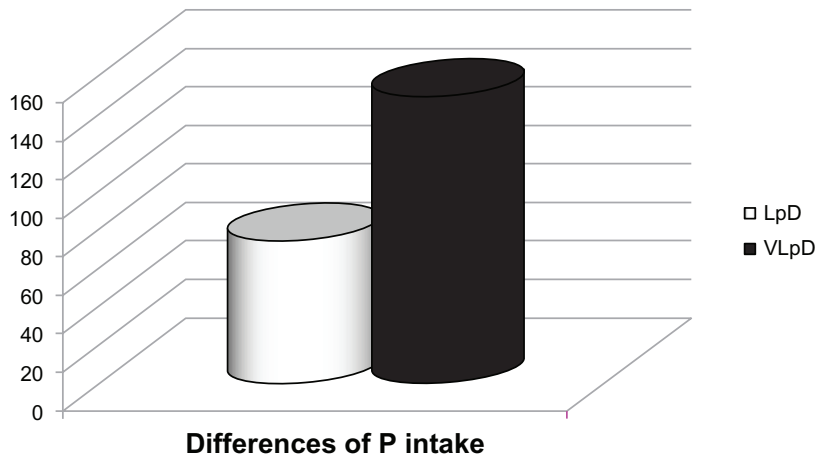

Figure I Differences in prescribed and observed dietary phosphorus intake ( $\mathrm{mg} /$ day). Abbreviations: LpD, low protein diet; VLpD, very low protein diet.

diet, with a difference of $74 \pm 35 \mathrm{mg}$ /day compared with the observed urinary phosphate $(P<0.001)$; in a very low protein diet, the urinary phosphate should be $316 \pm 27 \mathrm{mg} /$ day, representing a difference of $149 \pm 91 \mathrm{mg} /$ day $(P<0.001$, Figure 1). This significant difference between the observed and expected urinary phosphate in the two diets can only be explained with the phosphate contained in additives and beverages. ${ }^{17}$ In fact, in our study population, the amount of proteins ingested with the diet (evaluated from the urinary urea excretion) corresponded perfectly with the amount of dietary protein prescribed $(0.73 \pm 0.07$ in a low protein diet and $0.34 \pm 0.09$ in a very low protein diet). ${ }^{15}$ The dietetic interview performed with our patients demonstrated that beverage intake was $245 \pm 181 \mathrm{~mL} /$ day for red wine, $102 \pm 89 \mathrm{~mL} /$ day for cola, and $65 \pm 112 \mathrm{~mL} /$ day for fruit juice. Considering that the additives contained in the food ingested by our patients partially explained the differences in urinary phosphate levels, the beverages account for the additional phosphate intake of about $73 \mathrm{mg} /$ day for red wine, $17 \mathrm{mg} /$ day per cola, and $8 \mathrm{mg} /$ day for fruit juice, for a total of about $90-100 \mathrm{mg} /$ day.

\section{Conclusion}

Reduction of net intestinal absorption is the first goal during the earliest stages of chronic kidney disease, in order to prevent or to treat the onset of disordered bone mineral metabolism in patients with chronic kidney disease, such as an increase in FGF-23, inhibition of alfa-1-hydroxylase, reduced calcitriol, and an increase in synthesis and secretion of parathyroid hormone.

Therefore, the control and reduction in dietary intake of phosphorus are the first steps in the management of patients with chronic kidney disease. It is evident that there is variability in the phosphate content of beverages reported by the authors and by the Italian National Research Institute for Food and Feeding, and this problem needs to be taken 
into account in the management of patients with chronic kidney disease.

If patients are drinking various beverages with a high phosphate content, these could contribute to their hyperphosphatemia and to poor results obtained by treatment to reduce hyperphosphatemia. High dietary phosphorus intake has deleterious consequences for renal patients and may be harmful also for the general population. ${ }^{18}$ To prevent hyperphosphatemia, patients with end-stage renal disease must limit their intake of foods that are naturally rich in phosphorus, and education programs for end-stage renal disease patients aimed at avoiding phosphoruscontaining food and additives result in improved control of hyperphosphatemia. ${ }^{17}$

\section{Disclosure}

The authors report no conflicts of interest in this work.

\section{References}

1. Mizobuchi M, Towler D, Slatopolsky E. Vascular calcification: the killer of patients with chronic kidney disease. J Am Soc Nephrol. 2009;20: 1453-1464.

2. Cozzolino M, Mazzaferro S, Pugliese F, Brancaccio D. Vascular calcification and uremia: what do we know? Am J Nephrol. 2008;28: 339-346.

3. Messa P. Impact of $\mathrm{Ca} / \mathrm{P}$ disorders on risks and comorbidities. Contrib Nephrol. 2008;161:215-221.

4. Cozzolino M, Ciceri P, Volpi EM, Olivi L, Messa PG. Pathophysiology of calcium and phosphate metabolism impairment in chronic kidney disease. Blood Purif. 2009;27:338-344.

5. Burke SK. Phosphate is a uremic toxin. J Ren Nutr. 2008;18:27-32.
6. Gutiérrez OM, Mannstadt M, Isakova T, et al. Fibroblast growth factor 23 and mortality among patients undergoing hemodialysis. $N$ Engl $J$ Med. 2008;359:584-592.

7. Noori N, Kalantar-Zadeh K, Kovesdy CP, Bross R, Benner D, Kopple JD. Association of dietary phosphorus intake and phosphorus to protein ratio with mortality in hemodialysis patients. Clin J Am Soc Nephrol. 2010;5:683-692.

8. Moranne O, Froissart M, Rossert J, et al. Timing of onset of CKD-related metabolic complications. J Am Soc Nephrol. 2009;20:164-171.

9. Stubbs J, Liu S, Quarles LD. Role of fibroblast growth factor 23 in phosphate homeostasis and pathogenesis of disordered mineral metabolism in chronic kidney disease. Semin Dial. 2007;20:302-308.

10. Oliveira RB, Cancela AL, Graciolli FG, et al. Early control of PTH and FGF23 in normophosphatemic CKD patients: a new target in CKDMBD therapy? Clin J Am Soc Nephrol. 2010;5:286-291.

11. Cupisti A, D'Alessandro G. The impact of known and unknown dietary components to phosphorus intake. Giorn Ital Nefrologia. 2011;28: 278-288. Italian.

12. Savica V, Calò LA, Monardo P, et al. High phosphate content beverages in dialysis patients: Relevance for hyperphosphatemia and cardiovascular risk. Nutr Metab Cardiovasc Dis. 2008;18:e39-e40.

13. Kalantar-Zadeh K, Gutekunst L, Mehrotra R, et al. Understanding sources of dietary phosphorus in the treatment of patients with chronic kidney disease. Clin J Am Soc Nephrol. 2010;5:519-530.

14. Noori N, Sims JJ, Kopple JD et al. Organic and inorganic dietary phosphorus and its management in chronic kidney disease. Iran J Kidney Dis. 2010;4:89-100.

15. Di Iorio B, Di Micco L, Torraca S, et al. Acute effects of very-lowprotein diet on FGF23 levels: a randomized study. Clin J Am Soc Nephrol. 2012;7:581-587.

16. Moe SM, Zidehsarai MP, Chambers MA, et al. Vegetarian compared with meat dietary protein source and phosphorus homeostasis in chronic kidney disease. Clin J Am Soc Nephrol. 2011;6:257-264.

17. Sullivan C, Sayre SS, Leon JB, et al. Effect of food additives on hyperphosphatemia among patients with end-stage renal disease: a randomized controlled trial. JAMA. 2009;301:629-635.

18. Murtaugh MA, Filipowicz R, Baird BC, et al. Dietary phosphorus intake and mortality in moderate chronic kidney disease: NHANES III. Nephrol Dial Transplant. 2012;27:990-996.
Nutrition and Dietary Supplements

\section{Publish your work in this journal}

Nutrition and Dietary Supplements is an international, peer-reviewed, open access journal focusing on research into nutritional requirements in health and disease, impact on metabolism and the identification and optimal use of dietary strategies and supplements necessary for normal growth and development. The journal welcomes papers covering

\section{Dovepress}

original research, basic science, clinical \& epidemiological studies, reviews and evaluations, guidelines, expert opinion and commentary, case reports and extended reports. The manuscript management system is completely online and includes a very quick and fair peer-review system, which is all easy to use. 